\title{
EVALUASI KONDISI KETENAGAKERJAAN DI PROVINSI BENGKULU: TPAK, Economic Share, Employment Share
}

\author{
Afid Nurkholis \\ Email: afidnurkholis@gmail.com
}

\begin{abstract}
ABSTRAK
Ketenagakerjaan merupakan hal yang penting dalam perencanaan pembangunan. Kondisi ketenagakerjaan di Provinsi Bengkulu perlu dilakukan evaluasi. Bengkulu yang telah berdiri sebagai propinsi sejak tahun 1968 tentunya memiliki perkembangan dalam komponen ketenagakerjaan. Evaluasi terhadap TPAK, economic share, dan employment share pada penelitian ini dapat digunakan sebagai dasar perencanaan pembangunan manusia di Provinsi Bengkulu. TPAK Provinsi Bengkulu mengalami fluktuasi, yaitu mencapai titik terendah pada tahun 2000 sebagai dampak dari reformasi yang terjadi, namun kembali tinggi pada tahun 2010. Pertanian merupakan lapangan usaha tertinggi yang menyerap tenaga kerja, jasa merupakan lapangan usaha kedua, dan manufaktur merupakan yang paling rendah penyerapan tenaga kerjannya. Sementara itu, pertanian merupakan lapangan usaha dengan produktifitas paling tinggi (40\%), jasa adalah setelahnya, dan manufaktur merupakan yang paling rendah.
\end{abstract}

Katakunci: ketenagakerjaan, TPAK, economic share, employment share, Provinsi Bengkulu

\section{A. Pendahuluan}

\section{Latar Belakang}

Indonesia merupakan negara berkembang yang terus mencoba meningkatkan perekonomiannya untuk mencapai kesejahteraan bagi seluruh rakyat sesuai amanat UUD. Pertumbuhan ekonomi dapat dikatakan sebagai ukuran pembangunan suatu negara dari era klasik (zaman Adam Smith) hingga modern (era kapitalisme dan globalisasi sekarang). Seiring berjalannya waktu, para ahli mendefinisikan pertumbuhan ekonomi tidak hanya berdasarkan jumlah kenaikan arau penurunannya saja, namun muncul ukuran-ukuran baru yang diantaranya adalah pembangunan berbasis manusia (Dwiyanti, 2015).

Ketenagakerjaan merupakan hal yang penting dalam perencanaan pembangunan (Mantra, 2000). Data ketenagakerjaan merupakan salah satu 
aspek yang harus dimiliki dalam penyusunan pembangunan. Hal ini berkaitan dengan pembangunan yang pada dasarnya bertujuan menempatkan manusia sebagai obyek dan subyek dalam pembangunan.

Kesejahteraan manusia yang dalam teori pembangunan manusia diukur melalui tiga aspek (kesehatan, pendidikan, dan ekonomi) pada dasarnya dipengaruhi oleh pendapatan yang dimiliki. Penghasilan yang tinggi akan menjadikan manusia sadar akan kesehatan memiliki pendidikan tinggi yang pada akhirnya memiliki kesejahteraan tinggi.

Berdasarkan uraian diatas, kondisi ketenagakerjaan di Provinsi Bengkulu perlu dilakukan evaluasi. Bengkulu yang telah berdiri sebagai propinsi sejak tahun 1968 tentunya memiliki perkembangan dalam komponen ketenagakerjaan. Modernitas akan memengaruhi struktur penduduk, mata pencaharian dan pendapatan masyarakat. Selain itu, Indonesia yang dipredeksi mengalami bonus demografi tentunya juga berdampak pada Bengkulu. Provinsi Bengkulu yang memiliki angka DR 51 pada tahun 2010 akan mengalami bonus demografi dalam waktu dekat. Evaluasi terhadap TPAK, economic share, dan employment share pada penelitian ini dapat digunakan sebagai dasar perencanaan pembangunan manusia di Provinsi Bengkulu.

\section{Tujuan}

1. Menganalisis TPAK Provinsi Bengkulu pada tahun 1990, 2000, dan 2010.

2. Menganalisis economic share Provinsi Bengkulu pada tahun 1990, 2000, dan 2010.

3. Menganalisis employment share Provinsi Bengkulu pada tahun 1990, 2000, dan 2010.

\section{B. Metode Penilitan}

\section{Ketenagakerjaan}

Sumber Daya Manusia (SDM) atau Human Resources mengandung dua pengertian, yang pertama, SDM mengandung pengertian usaha kerja atau jasa yang dapat diberikan dalam proses produksi, kedua, SDM menyangkut manusia yang mampu bekerja untuk memberikan jasa atau usaha kerja. Bekerja dapat 
diartikan melakukan kegiatan yang mempunyai nilai ekonomis yaitu bahwa kegiatan tersebut menghasilkan barang atau jasa untuk memenuhi kebutuhan masyarakat (Mantra, 2004). Secara fisik kemampuan bekerja diukur dengan usia, dengan kata lain orang dalam usia kerja tersebut dianggap mampu bekerja. Kelompok penduduk dalam usia kerja tersebut dinamakan tenaga kerja tau manpower. Secara singkat, tenaga kerja didefinisikan sebagai penduduk dalam usia kerja .

Dalam studi mengenai ketenagakerjaan terdapat beberapa istilah dasar yang harus diketahui perbedaannya. Istilah tersebut diantaranya adalah penduduk usia kerja, angakatan kerja, bekerja, dan pengangguran. Istilah-istilah tersebut merupakan suatu bagan ketenagakerjaan yang dapat dilihat di Gambar 1. BPS mendefinisikan usia kerja adalah penduduk yang memiliki umur 15 - 64 tahun. Rentang umur tersebut dianggap usia seseorang yang dapat bekerja atau produktif. Penduduk usia kerja dibedakan menjadi dua yaitu angkatan kerja dan bukan angkatan kerja. Bukan angkatan kerja (BAK) adalah orang yang tidak bekerja karena suatu hal seperti sekolah, pensiunan, mengurus rumah tangga. Bekerja merupakan aktifitas menghasilkan atau membantu menghasilkan suatu produk yang bernilai ekonomi dengan minimal waktu 1 jam seminggu selama berturutturut. Seseorang yang tidak tergolong bekerja dikategorikan sebagai pengangguran.

Batasan istilah ketenagakerjaan tersebut dapat berbeda-beda disetiap negara. Perbedaan batasan dapat mengakibatkan hasil proyeksi yang berbedabeda. Oleh karena itu, sebuah pendekatan yang jelas perlu ada untuk menyusun konsep yang jelas. Saat ini ada tiga pendekatan mengenai ketenagakerjaan, yaitu:

\section{a. Gaintfull Worker Approach (GWA)}

Pendekatan ini mendefinisikan bekerja sebagai aktifitas yang biasa dilakukan oleh seseorang. Misalnya adalah seseorang yang biasanya sekolah ketika saat disurvei tengah mencari pekerjaan tetap dianggap sebagai anak sekolah.

\section{b. Labour Force Approach (LFA)}


Pendekatan ini mendefinisikan aktifitas bekerja berdasar waktu. Indonesia menggunakan batasan waktu minimal 1 jam berturut-turut dalam satu minggu.

\section{c. Labour Utilization Approach (LUA)}

Pendekatan ini menggunakan batasan pemanfaatan tenaga kerja dalam definisi bekerja. Pemanfaatan yang dimaksud terdiri dari tiga komponen, yaitu jumlah jam kerja, kesesuaian pendidikan dengan pekerjaan, dan upah yang didapat. Oleh karena itu, dalam pendekatan ini telah muncul konsep setengah pengangguran yaitu orang yang bekerja namun tidak termanfaatkan salah satu atau seluruh tiga komponen diatas.

\section{Gambar 1 : Bagan ketenagakerjaan Indonesia}

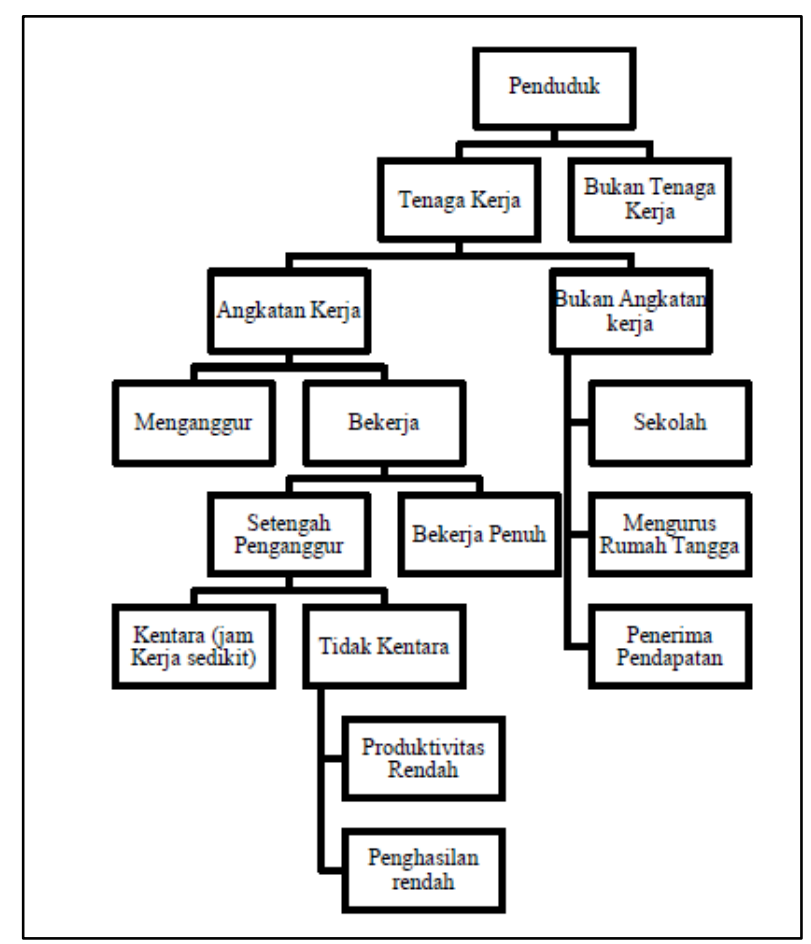

Sumber : Mantra, 2004

\section{TPAK}

TPAK atau Tingkat Partisipasi Angkatan Kerja adalah angka yang menunjukkan presentase angkatan kerja terhadap penduduk usia kerja (Mantra, 2000). Angka TPAK digunakan sebagai dasar untuk mengetahui penduduk yang aktif bekerja ataupun mecari pekerjaan. TPAK dipengaruhi oleh faktor 
jumlah penduduk yang sedang sekolah maupun mengurus rumah tangga dimana kedua hal tesebut berkaitan dengan kondisi sosial budaya masyarakat. Pengukuran TPAK dilakukan sebagai berikut:

\section{TPAK $=($ Jumlah Angkatan Kerja/Jumlah Penduduk Usia Kerja $) \times 100$}

\section{Pembahasan}

\section{TPAK}

TPAK Provinsi Bengkulu pada tahun 1990, 2000, dan 2010 menunjukkan flukuasi (Gambar 2) baik itu TPAK total, laki-laki, maupun perempuan. Nilai TPAK total pada tahun 1990 adalah 60, pada tahun 2000 adalah 43 dan pada tahun 2010 adalah 75 (Tabel 1). Nilai TPAK tersebut merupakan perbandingan antara penduduk yang bekerja dengan yang penduduk usia kerja, sehingga semakin tinggi penduduk yang bekerja maka nilai TPAK akan semakin tinggi begitupun sebaliknya.

Gambar 2: TPAK Tahun 1990, 2000, 2010

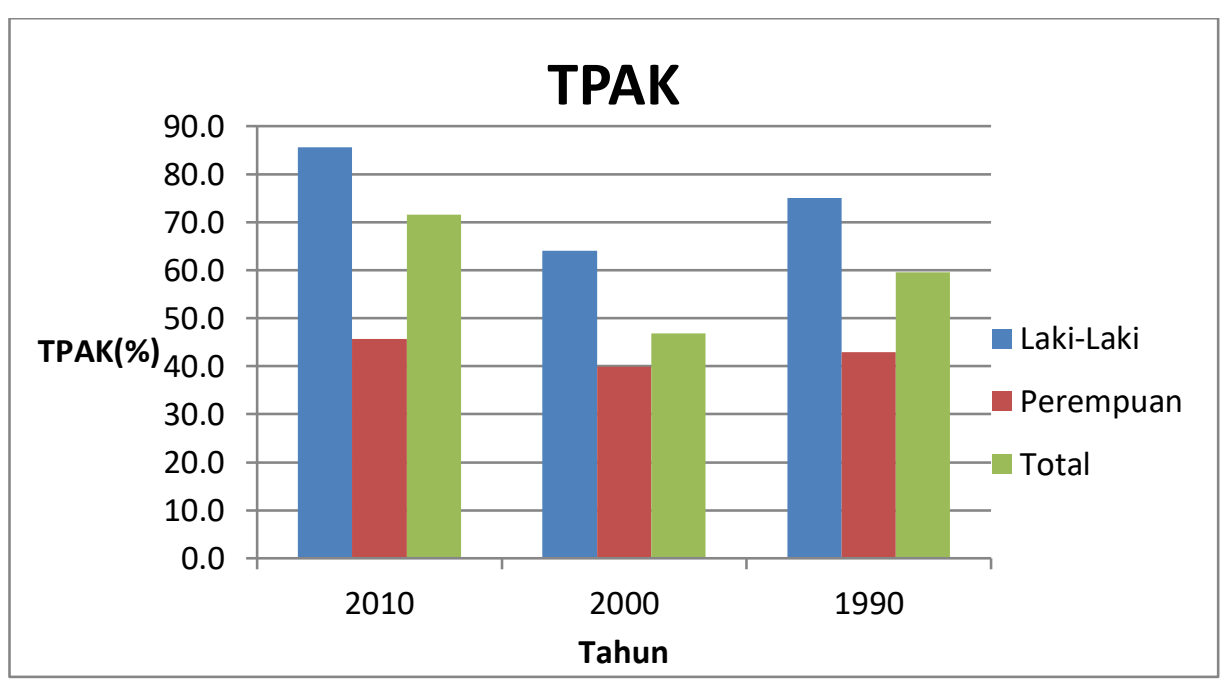

Sumber: BPS dengan pengolahan, 2016

Nilai TPAK secara keseluruhan mengalami penurunan drastis pada tahun 2000. Hal ini ditunjukkan dengan jumlah penduduk yang bekerja pada tahun 2000 adalah 29.455 jiwa, sedangkan pada tahun 1990 adalah sebesar 
306.699 jiwa. Sementara itu, jumlah penduduk usia kerja pada tahun 2000 adalah yang paling tinggi di ketiga periode waktu dengan nilai 963.715 jiwa (Tabel 1). Data tersebut menunjukkan bahwa penduduk Provinsi Bengkulu pada tahun 2000 memiliki jumlah tenaga kerja sedikit, namun serapan lapangan kerja rendah.

Rendahnya serapan tenaga kerja pada tahun 2000 dapat dikaitkan dengan situasi politik Indonesia. Reformasi pergantian Presiden Soeharto dan krisis moneter yang terjadi merupakan sebab utama banyaknya pengangguran. Jumlah penduduk lansia pada tahun 2000 adalah 47.899 jiwa dan pekerja perempuan adalah 484.164 jiwa. Data ini menguatkan analisis bahwa rendahnya TPAK tahun 2000 disebabkan oleh jumlah pengangguran yang tinggi.

Tabel 1: TPAK Tahun 1990, 2000, 2010

\begin{tabular}{|c|c|c|c|c|}
\hline Tahun & Keterangan & Laki-Laki & Perempuan & Total \\
\hline \multirow{4}{*}{2010} & Bekerja & 497,962 & 317,656 & 815,618 \\
\cline { 2 - 5 } & Pengangguran Terbuka & 21,649 & 56,108 & 77,757 \\
\cline { 2 - 5 } & Angakatan Kerja & 519,611 & 373,764 & 893,375 \\
\cline { 2 - 5 } & Bukan Angkatan Kerja & 85,779 & 209,137 & 294,916 \\
\cline { 2 - 5 } & Penduduk Usia Kerja & 607,313 & 583,695 & $1,191,008$ \\
\cline { 2 - 5 } & TPAK & 85.6 & 64.0 & 75 \\
\hline \multirow{5}{*}{2000} & Bekerja & 423,264 & 324,014 & 747,278 \\
\cline { 2 - 5 } & Pengangguran Terbuka & 16,771 & 12,684 & 29,455 \\
\cline { 2 - 5 } & Angakatan Kerja & 440,035 & 336,698 & 776,733 \\
\cline { 2 - 5 } & Bukan Angkatan Kerja & 523,680 & 507,760 & $1,031,440$ \\
\cline { 2 - 5 } & Penduduk Usia Kerja & 963,715 & 844,458 & $1,808,173$ \\
\cline { 2 - 5 } & TPAK & 45.7 & 39.9 & 43 \\
\hline \multirow{5}{*}{1990} & Bekerja & 306,699 & 189,423 & 496,122 \\
\hline
\end{tabular}

Sumber: BPS dengan pengolahan, 2016

TPAK pada tahun 2010 mulai meningkat kembali. Nilai ini merupakan yang paling tinggi selama tiga periode waktu. Perekonomian Indonesia yang 
mulai membaik menjadikan serapan tenaga kerja menjadi tinggi. Nilai tersebut menunjukkan bahwa 3/4 dari penduduk usia produktif di Provinsi Bengkulu bekerja. Nilai TPAK yang tinggi tersebut juga didukung dependendy ratio Bengkulu yang rendah, yaitu 51 pada tahun 2010. Tingginya penduduk yang bekerja ini perlu diukur produktifitasnya karena bekerja belum tentu memiliki produktifitas yang berkaitan dengan kesejateraan yang tinggi pula.

Perbedaan gender masih terlihat dalam partisipasi kerja di Provinsi Bengkulu. Selama tiga periode waktu, penduduk perempuan selalu memiliki TPAK yang rendah dibandingkan laki-laki (Tabel 1). Hal ini menunjukkan bahwa perempuan masih dianggap lebih baik tidak bekerja dan megurus rumah tangga (subordinasi perempuan). Meskipun demikian, TPAK perempuan dibandingkan TPAK laki-laki meningkat 9,3\% dari tahun 1990 ke tahun 2000. Hal ini merupakan sebuah pertanda baik terhadap pembangunan di Bengkulu. Produktifitas dan kesejahteraan penduduk tidak terlepas dari peran perempuan.

TPAK Bengkulu dibandingkan dengan nilai provinsi secara nasional dapat dilihat dari Tabel 2, 3, dan 4. Tabel tersebut menunjukkan bahwa pada tahun 1990 TPAK Bengkulu berada pada level menengah, tahun 2000 pada kelas paling bawah dan pada tahun 2010 meingkat menjadi level atas. Keadaan ini menjadi bukti bahwa perkembangan ketenagakerjaa di Provinsi Bengkulu mengalami peningkatan. Sementara itu, secara nasional perempuan tetap mengalami diskrimnasi dalam hal pekerjaan. Hal ini dibuktikan dengan nilai TPAK perempuan yang selalu dibawah laki-laki.

\section{Employment Share}

Employment share diartikan sebagai jumlah tenaga kerja disetiap lapangan usaha utama yang tersedia. Lapangan usaha di Provinsi Bengkulu diklasifikasin menjadi 9 bagian (Tabel 5). Jumlah tenaga kerja disetiap lapangan usaha ini dapat digunakan untuk menganalisis lapangan pekerjaan utama dan tingkat modernitas Provinsi Bengkulu. Gambar 3 dan 4 menunjukkan bahwa sektor pertanian merupakan lapangan pekerjaan utama di 
Provinsi Bengkulu. Tahun 2010 menunjukkan bahwa pekerja di sektor ini berjumlah $62 \%$ dengan $37 \%$ laki-laki dan $25 \%$ perempuan.

Tabel 5: Employment Share Setiap Lapangan Usaha

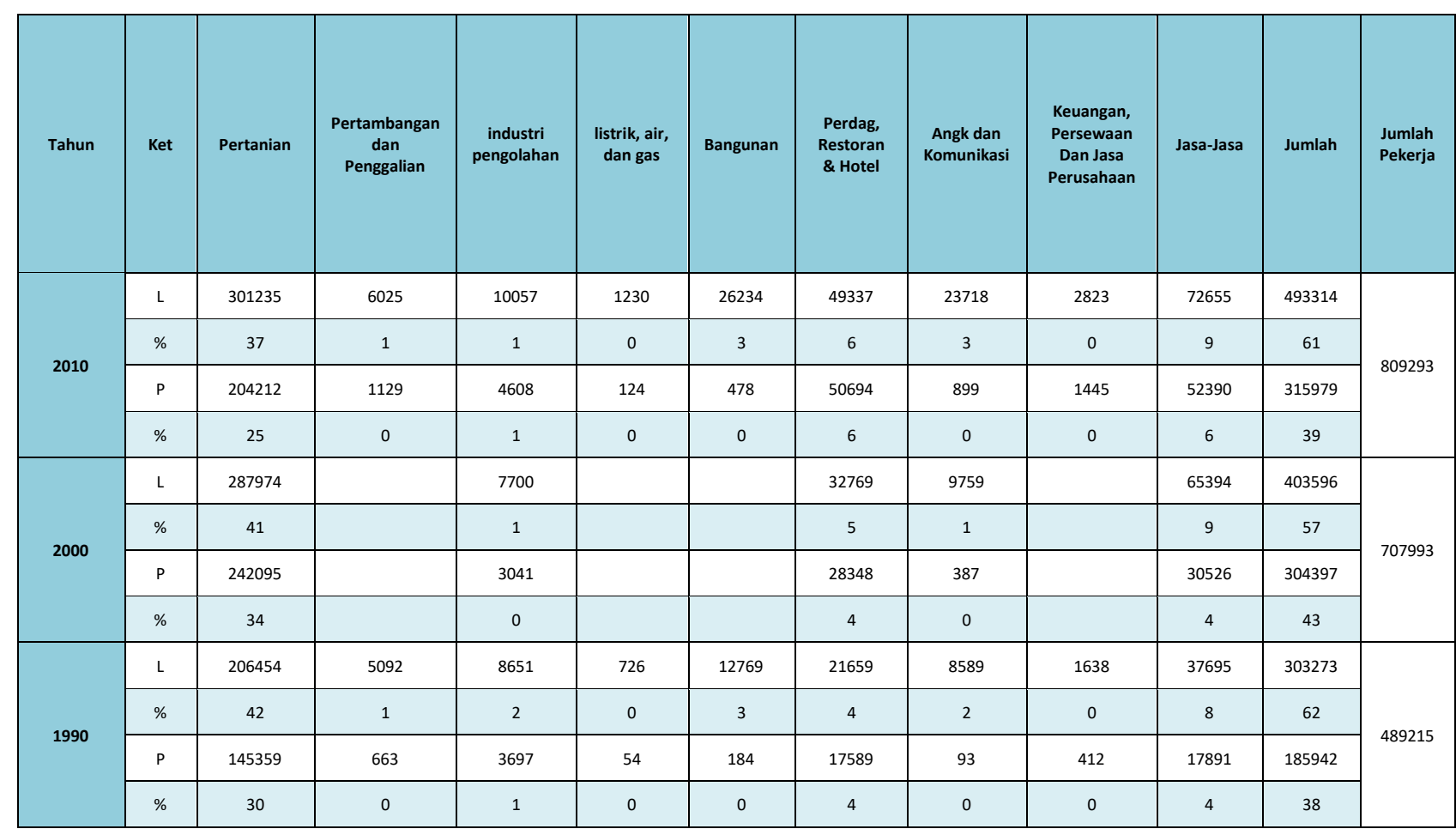

Sumber: BPS dengan pengolahan, 2016

Data tersebut menunjukkan bahwa sejak tahun 1990 hingga 2010 sektor pertanian masih mampu menopang perekonomian Provinsi Bengkulu. Produktivitas sektor lapangan usaha akan dibahas pada bab economis share.

Sektor terbesar kedua yang memberikan lapangan pekerjaan adalah jasa dan perdagangan, restoran, hotel. Kedua sektor tersebut dapat dikaterogikan sebagai jasa. Perkembangan ekonomi daerah yang modern adalah dimana pekerjaan penduduk banyak pada sektor jasa. Provinsi Bengkulu hingga tahun 2010 masih didominasi oleh sektor pertanian, sehingga dapat dikatakan masih tradisional. Meskipun demikian, Tabel 5 menunjukkan bahwa sektor pertanian dari tahun 1990, 2000, 2010 terus mengalami penurunan tenaga kerja. Penurunan tersebut dibarengi dengan naiknya jumlah pekerja pada sektor jasa. Hal ini diakibatkan seiring adanya modernisasi dan industrialisasi sektor jasa 
akan mulai tumbuh menggantikan sektor pertanian, namun sektor pertanian masih jauh mendomonasi hingga tahun 2010.

Gambar 3: Employment Share Laki-Laki Tahun 1990, 2000, 2010

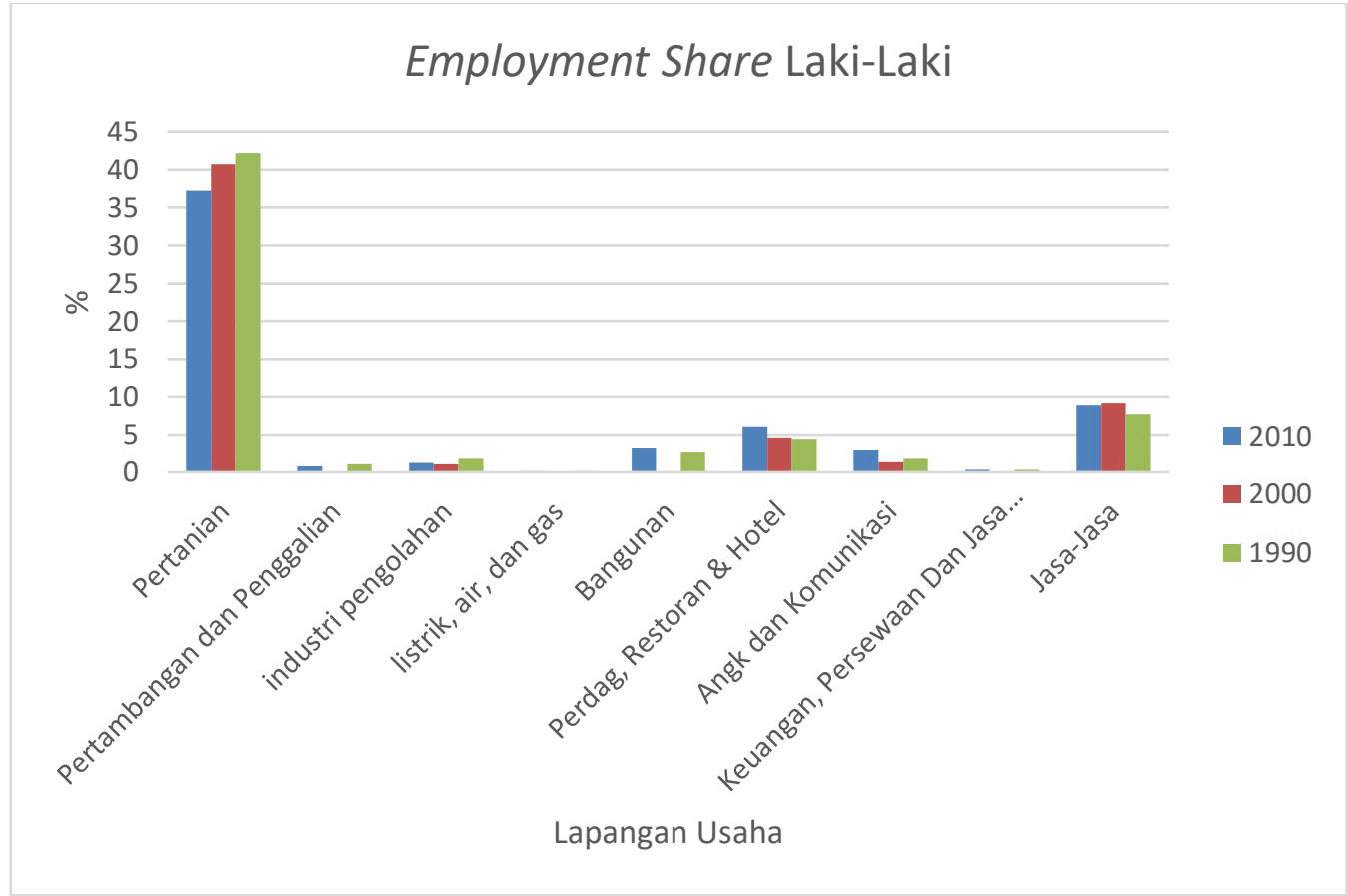

Sumber: BPS dengan pengolahan, 2016

Gambar 4: Employment Share Perempuan Tahun 1990, 2000, 2010

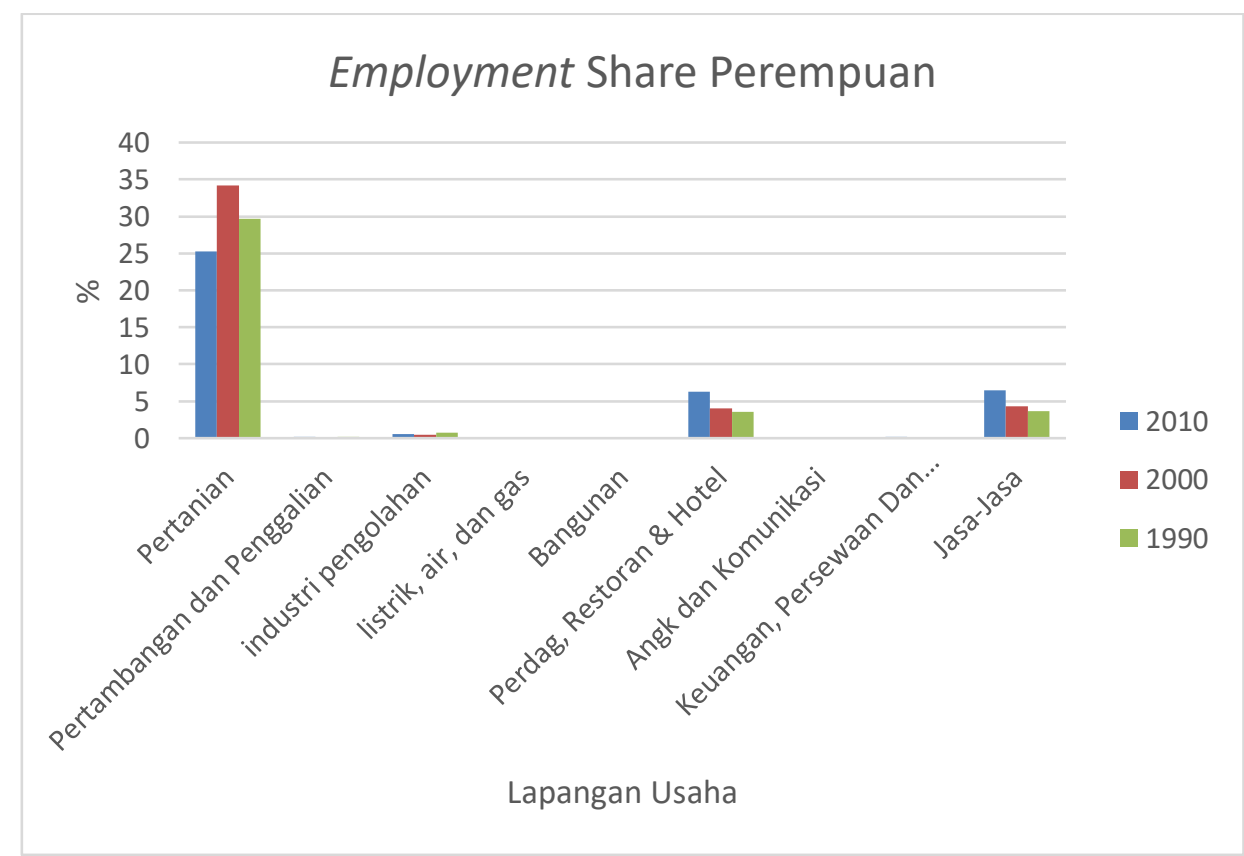

Sumber: BPS dengan pengolahan, 2016 
Tabel 2: TPAK Provinsi Seluruh Indonesia Tahun 1990

\begin{tabular}{|c|c|c|c|c|}
\hline \multirow{2}{*}{ No } & \multirow{2}{*}{ Provinsi } & \multicolumn{2}{|c|}{ TPAK } & \multirow[b]{2}{*}{ TPAK } \\
\hline & & Laki-laki & Perempuan & \\
\hline 1 & Aceh & 82.90 & 44.22 & 63.38 \\
\hline 2 & Sumatera Utara & 79.68 & 49.64 & 66.30 \\
\hline 3 & Sumatera Barat & 78.51 & 43.53 & 60.09 \\
\hline 4 & Riau & 91.03 & 34.99 & 60.76 \\
\hline 5 & Jambi & 72.79 & 48.23 & 43.17 \\
\hline 6 & Sumatera Selatan & 69.78 & 40.11 & 54.95 \\
\hline 7 & Bengkulu & 71.52 & 46.88 & 59.53 \\
\hline 8 & Lampung & 94.89 & 1.37 & 56.85 \\
\hline 9 & Kepulauan Bangka Belitung & 69.77 & 40.11 & 54.95 \\
\hline 10 & Kepulauan Riau* & 91.03 & 34.99 & 60.76 \\
\hline 11 & DKI Jakarta & 77.08 & 34.22 & 55.68 \\
\hline 12 & Jawa Barat & 70.08 & 29.55 & 49.72 \\
\hline 13 & Jawa Tengah & 72.74 & 45.06 & 58.57 \\
\hline 14 & DI Yogyakarta & 70.32 & 56.88 & 63.44 \\
\hline 15 & Jawa Timur & 85.74 & 48.19 & 67.26 \\
\hline 16 & Banten* & 70.08 & 29.55 & 49.72 \\
\hline 17 & Bali & 72.40 & 54.50 & 63.37 \\
\hline 18 & Nusa Tenggara Barat & 76.55 & 48.86 & 62.17 \\
\hline 19 & Nusa Tenggara Timur & 76.69 & 54.51 & 65.02 \\
\hline 20 & Kalimantan Barat & 73.71 & 48.15 & 61.18 \\
\hline 21 & Kalimantan Tengah & 87.83 & 88.45 & 79.73 \\
\hline 22 & Kalimantan Selatan & 71.71 & 35.55 & 57.85 \\
\hline 23 & Kalimantan Timur & 89.63 & 39.81 & 66.13 \\
\hline 24 & Sulawesi Utara & 70.67 & 31.68 & 51.34 \\
\hline 25 & Sulawesi Tengah & 72.49 & 35.73 & 54.55 \\
\hline 26 & Sulawesi Selatan & 66.89 & 22.97 & 44.05 \\
\hline 27 & Sulawesi Tenggara & 70.06 & 37.67 & 53.55 \\
\hline 28 & Gorontalo & 70.67 & 29.39 & 62.77 \\
\hline 29 & Sulawesi Barat* & 66.89 & 22.97 & 44.05 \\
\hline 30 & Maluku & 66.18 & 32.71 & 49.55 \\
\hline 31 & Maluku Utara* & 66.18 & 32.71 & 77.04 \\
\hline 32 & Papua Barat & 70.72 & 50.24 & 60.95 \\
\hline 33 & Papua & 70.72 & 50.24 & 60.95 \\
\hline & TPAK Tertinggi & 94.89 & 88.45 & 79.73 \\
\hline & TPAK Terendah & 66.18 & 1.37 & 43.17 \\
\hline
\end{tabular}

Sumber: BPS dengan pengolahan, 2016 
Tabel 3: TPAK Provinsi Seluruh Indonesia Tahun 2000

\begin{tabular}{|c|c|c|c|c|}
\hline \multirow{2}{*}{ No } & \multirow{2}{*}{ Provinsi } & \multicolumn{2}{|r|}{ TPAK } & \multirow{2}{*}{ TPAK } \\
\hline & & Laki-laki & Perempuan & \\
\hline 1 & Aceh & 81.27 & 51.89 & 66.62 \\
\hline 2 & Sumatera Utara & 98.10 & 37.78 & 67.49 \\
\hline 3 & Sumatera Barat & 79.61 & 54.35 & 66.45 \\
\hline 4 & Riau & 87.26 & 52.74 & 70.23 \\
\hline 5 & Jambi & 85.34 & 60.48 & 60.80 \\
\hline 6 & Sumatera Selatan & 82.03 & 63.41 & 72.76 \\
\hline 7 & Bengkulu & 45.66 & 39.87 & 42.96 \\
\hline 8 & Lampung & 90.61 & 73.52 & 77.80 \\
\hline 9 & Kepulauan Bangka Belitung & 84.46 & 50.83 & 68.05 \\
\hline 10 & Kepulauan Riau* & 87.26 & 52.74 & 70.32 \\
\hline 11 & DKI Jakarta & 81.30 & 44.24 & 62.96 \\
\hline 12 & Jawa Barat & 81.06 & 48.07 & 64.83 \\
\hline 13 & Jawa Tengah & 84.49 & 66.99 & 75.61 \\
\hline 14 & DI Yogyakarta & 76.35 & 64.32 & 70.22 \\
\hline 15 & Jawa Timur & 83.84 & 48.58 & 67.64 \\
\hline 16 & Banten & 78.74 & 83.35 & 63.97 \\
\hline 17 & Bali & 87.61 & 78.34 & 82.98 \\
\hline 18 & Nusa Tenggara Barat & 85.40 & 68.29 & 76.36 \\
\hline 19 & Nusa Tenggara Timur & 86.79 & 77.59 & 82.06 \\
\hline 20 & Kalimantan Barat & 86.43 & 65.66 & 76.22 \\
\hline 21 & Kalimantan Tengah & 89.02 & 67.99 & 77.48 \\
\hline 22 & Kalimantan Selatan & 58.04 & 55.72 & 71.85 \\
\hline 23 & Kalimantan Timur & 87.50 & 42.53 & 66.24 \\
\hline 24 & Sulawesi Utara & 82.24 & 48.11 & 65.50 \\
\hline 25 & Sulawesi Tengah & 86.56 & 61.26 & 74.17 \\
\hline 26 & Sulawesi Selatan & 80.67 & 45.91 & 62.49 \\
\hline 27 & Sulawesi Tenggara & 84.08 & 61.64 & 72.73 \\
\hline 28 & Gorontalo & 82.24 & 48.11 & 65.50 \\
\hline 29 & Sulawesi Barat* & 80.67 & 45.91 & 62.49 \\
\hline 30 & Maluku & 79.52 & 60.80 & 70.12 \\
\hline 31 & Maluku Utara* & 79.52 & 60.80 & 74.84 \\
\hline 32 & Papua Barat* & 69.86 & 86.30 & 78.50 \\
\hline 33 & Papua & 69.86 & 86.30 & 78.50 \\
\hline & TPAK Tertinggi & 98.10 & 86.30 & 82.98 \\
\hline & TPAK Terendah & 45.66 & 37.78 & 42.96 \\
\hline
\end{tabular}

Sumber: BPS dengan pengolahan, 2016 
Tabel 4: TPAK Provinsi Seluruh Indonesia Tahun 2010

\begin{tabular}{|c|c|c|c|c|}
\hline \multirow{2}{*}{ No } & \multirow{2}{*}{ Provinsi } & \multicolumn{2}{|c|}{ TPAK } & \multirow{2}{*}{ TPAK } \\
\hline & & Laki-laki & Perempuan & \\
\hline 1 & Aceh & 81.63 & 57.46 & 69.41 \\
\hline 2 & Sumatera Utara & 82.62 & 54.51 & 68.34 \\
\hline 3 & Sumatera Barat & 80.70 & 50.99 & 65.46 \\
\hline 4 & Riau & 83.72 & 42.34 & 63.66 \\
\hline 5 & Jambi & 85.75 & 49.61 & 62.97 \\
\hline 6 & Sumatera Selatan & 84.66 & 55.41 & 70.23 \\
\hline 7 & Bengkulu & 85.56 & 64.03 & 75.01 \\
\hline 8 & Lampung & 61.55 & 42.20 & 67.95 \\
\hline 9 & Kepulauan Bangka Belitung & 92.02 & 46.20 & 69.23 \\
\hline 10 & Kepulauan Riau & 88.63 & 42.77 & 66.29 \\
\hline 11 & DKI Jakarta & 82.88 & 47.63 & 65.43 \\
\hline 12 & Jawa Barat & 84.92 & 45.34 & 65.38 \\
\hline 13 & Jawa Tengah & 85.03 & 62.58 & 73.60 \\
\hline 14 & DI Yogyakarta & 79.89 & 64.92 & 72.23 \\
\hline 15 & Jawa Timur & 85.79 & 59.97 & 69.48 \\
\hline 16 & Banten & 83.35 & 46.23 & 65.15 \\
\hline 17 & Bali & 86.88 & 71.31 & 79.14 \\
\hline 18 & Nusa Tenggara Barat & 59.28 & 43.88 & 51.45 \\
\hline 19 & Nusa Tenggara Timur & 83.56 & 62.61 & 74.41 \\
\hline 20 & Kalimantan Barat & 82.84 & 53.04 & 68.25 \\
\hline 21 & Kalimantan Tengah & 65.64 & 58.01 & 74.92 \\
\hline 22 & Kalimantan Selatan & 85.78 & 55.72 & 70.82 \\
\hline 23 & Kalimantan Timur & 89.93 & 44.22 & 68.51 \\
\hline 24 & Sulawesi Utara & 78.99 & 34.82 & 57.27 \\
\hline 25 & Sulawesi Tengah & 87.69 & 49.90 & 69.22 \\
\hline 26 & Sulawesi Selatan & 76.67 & 38.28 & 56.58 \\
\hline 27 & Sulawesi Tenggara & 86.70 & 57.81 & 72.13 \\
\hline 28 & Gorontalo & 83.61 & 49.63 & 66.49 \\
\hline 29 & Sulawesi Barat & 87.33 & 64.20 & 71.46 \\
\hline 30 & Maluku & 79.12 & 57.07 & 68.03 \\
\hline 31 & Maluku Utara & 80.92 & 54.63 & 88.36 \\
\hline 32 & Papua Barat & 82.40 & 54.65 & 68.52 \\
\hline 33 & Papua & 88.56 & 72.72 & 80.99 \\
\hline & TPAK Tertinggi & 92.02 & 72.72 & 88.36 \\
\hline & TPAK Terendah & 59.28 & 34.82 & 51.45 \\
\hline
\end{tabular}

Sumber: BPS dengan pengolahan, 2016 
Permasalahan gender juga terlihat dalam pekerja menurut lapangan usaha ini. Tabel 5 menunjukkan bahwa perempuan mengalami subordinasi di beberapa pekerjaan tertentu. Pekerjaan bangunan selalu didominasi oleh lakilaki. Hal ini diakibakan oleh perempuan yang dianggap lemah dan tidak pantas bekerja di sektor ini. Sementara itu, disetiap lapangan usaha yang lain perempuan juga memiliki presentasi rendah dibanfingkan laki-laki. Pekerjaan yang tidak membutuhkan tenaga besar, seperti perdagangan, restoran dan perhotelan jumlah pekerja perempuan hampir menyamai hingg sama dengan laki-laki.

\section{Economic Share}

Economic share diartikan sebagai kontribusi setiap lapangan usaha terhadap pendapatan di suatu wilayah. Lapangan usaha yang digunakan di penelitian ini sama dengan yang dibahas di employment share. Pendapatan yang dimaksud adalah PDRB (Produk Domestik Regional Bruto). PDRB yang digunakan untuk analisis adalah berdasar harga berlaku. Hal ini dikarenakan nilai yang ada dapat mewakili harga pasar. PDRB konstan sumber data berasal dari harga tahun 2000 yang dianggap sudah tidak dapat mewakili.

Tabel 6: Economic Share (dalam juta)

\begin{tabular}{|c|c|c|c|c|c|c|c|c|c|c|c|}
\hline Tahun & Ket & Pertanian & $\begin{array}{c}\text { Pertambangan } \\
\text { dan } \\
\text { Penggalian }\end{array}$ & $\begin{array}{c}\text { industri } \\
\text { pengolahan }\end{array}$ & $\begin{array}{l}\text { listrik, } \\
\text { air, dan } \\
\text { gas }\end{array}$ & Bangunan & $\begin{array}{l}\text { Perdag, } \\
\text { Restoran } \\
\text { \& Hotel }\end{array}$ & $\begin{array}{l}\text { Angk dan } \\
\text { Komunikasi }\end{array}$ & $\begin{array}{c}\text { Keuangan, } \\
\text { Persewaan Dan } \\
\text { Jasa Perusahaan }\end{array}$ & Jasa-Jasa & Jumlah \\
\hline \multirow{4}{*}{2010} & Konstan & 561 & 320,403 & 352,683 & 43,942 & 261,107 & $1,659,948$ & 693,527 & 396,129 & $1,449,447$ & $5,177,747$ \\
\hline & $\%$ & 0 & 6 & 7 & 1 & 5 & 32 & 13 & 8 & 28 & 100 \\
\hline & Berlaku & $7,441,060$ & 774,016 & 785,713 & 100,014 & 678,265 & $3,540,326$ & $1,493,049$ & 833,785 & $2,953,887$ & $18,600,117$ \\
\hline & $\%$ & 40 & 4 & 4 & 1 & 4 & 19 & 8 & 4 & 16 & 100 \\
\hline \multirow{4}{*}{2000} & Konstan & 567,320 & 53,498 & 82,882 & 18,731 & 51,367 & 283,067 & 264,962 & 106,317 & 315,988 & $1,744,132$ \\
\hline & $\%$ & 33 & 3 & 5 & 1 & 3 & 16 & 15 & 6 & 18 & 100 \\
\hline & Berlaku & $1,856,507$ & 151,233 & 226,027 & 20,381 & 115,995 & 793,693 & 539,322 & 208,213 & 628,613 & $4,539,984$ \\
\hline & $\%$ & 41 & 3 & 5 & 0 & 3 & 17 & 12 & 5 & 14 & 100 \\
\hline \multirow{4}{*}{1990} & Konstan & 152,199 & 25,868 & 13,734 & 3,000 & 42,587 & 51,039 & 57,218 & 10,022 & 64,211 & 419,878 \\
\hline & $\%$ & 36 & 6 & 3 & 1 & 10 & 12 & 14 & 2 & 15 & 100 \\
\hline & Berlaku & 275,169 & 40,347 & 23,859 & 5,477 & 74,953 & 102,793 & 107,509 & 16,941 & 159,672 & 806,720 \\
\hline & $\%$ & 34 & 5 & 3 & 1 & 9 & 13 & 13 & 2 & 20 & 100 \\
\hline
\end{tabular}

Sumber: BPS dengan pengolahan, 2016 
Gambar 5: Economi Share Tahun 1990, 2000, 2010

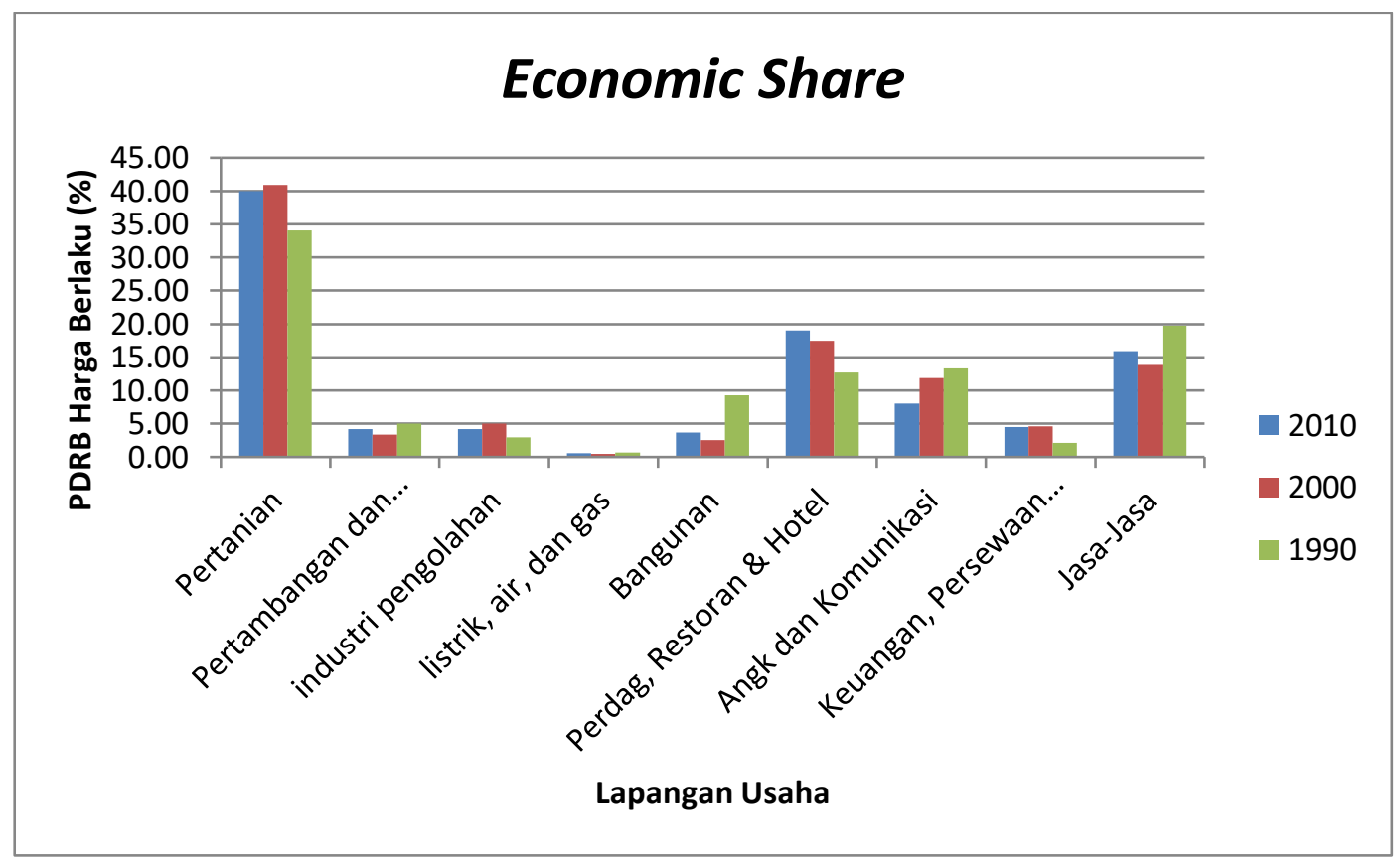

Sumber: BPS dengan pengolahan, 2016

Gambar 5 menunjukkan bahwa lapangan pekerjaan pertanian merupakan yang paling besar menyumbang pendapatan daerah pada ketiga periode waktu. Pertanian menyumbang PDRB sebesar rata-rata $40 \%$. Hal ini tergolong dominan dibandingkan sektor lain. Tingginya penghasilan sektor pertanian ini sejalan dengan jumlah pekerja yang berada di lapangan usaha ini. Data ini menunjukkan bahwa petani di Bengkulu berpotensi sejahtera.

Pertanian di daerah ini berkembang karena tletak geografis yang mendukung. Musim di Bengkulu yang dipengaruhi muson menjadikannya memiliki curah hujan tinggi dan waktu tanam jelas. Sementara itu, tanah di daerah ini juga tergolong subur. Topografi Bengkulu dibagi menjadi tiga yaitu, Pegunungan Bukit Barisan di Timur, dataran alluvial di Tengah, dan Pesisir di Selatan. Pegunungan tersebut tidak luas dibandingkan dengan dataran yang ada. Selain itu, gunungapi yang berada di sekitar Provinsi Bengkulu baik itu tersier maupun kuarter juga menjadi sebab suburnya tanah. Material hasil endapan sungai 
dan abu gunungapi merupakan sebab utama tanah di wilayah ini cocok untuk pertanian.

Lapangan usaha yang paling sedikit menyumbang PDRB adalah manufaktur yang terdiri dari pertambangan dll, listrik dll, dan industi pengolahan. Pertambangan di Bengkulu tidak intensif berkaitan dengan sumber daya alam yang memang terbatas. Letak secara geoglogi daerah ini berada di barat Sumatera dimana proses yang dominan adalah fluvial dan struktural. Hal ini menjadikan bahan tambang seperti batubara, minyak, dan mineral berharga lain tidak banyak. Industti juga tidak berkembang karena Provinsi Bengkulu yang bukan merupakan sentral pembangunan Indonesia, sehingga investor tidak banyak tertarik untuk membangun industry besar.

Lapangan usaha jasa merupakan sektor kedua setelah pertanian dalam hal produktifitas meskipun memang nilainya masih terpaut cukup jauh (Tabel 6). Lapangan usaha jasa merupakan ciri dari sebuah daerah yang modern atau urban. Globalisasi menjadikan Bengkulu juga berkembang kea rah moderenitas. Hal ini terlihat dari perkembangan produktifitas sektor jasa dari tahun 1990 - 2010 yang terus meningkat. Lapangan usaha yang terus meningkat adalah sektor perdagangan dan perhotelan. Hal ini berkaitan dengan sektor pariwisata yang juga semakin berkembang.

\section{KESIMPULAN}

1. TPAK Provinsi Bengkulu mengalami fluktuasi, yaitu mencapai titik terendah pada tahun 2000 sebagai dampak dari reformasi yang terjadi, namun kembali tinggi pada tahun 2010. TPAK perempuan menunjukkan bahwa pekerja perempuan jumlahnya terus meningkat.

2. Pertanian merupakan lapangan usaha tertinggi yang menyerap tenaga kerja., jasa merupakan lapangan usaha kedua, dan manufaktur merupakan yang paling rendah penyerapan tenaga kerjannya.

3. Pertanian merupakan lapangan usaha dengan produktifitas paling tinggi (40\%), jasa adalah setelahnya, dan manufaktur merupakan yang paling rendah. Hal ini berkorelasi positif dengan jumlah serapan tenaga kerja Provinsi Bengkulu. 


\section{DAFTAR PUSTAKA}

BPS. 1990. Sensus Penduduk Tahun 1990. Jakarta: BPS

BPS. 2000. Sensus Penduduk Tahun 2000. Jakarta: BPS

BPS. 2010. Sensus Penduduk Tahun 2010. Jakarta: BPS

Mantra, Ida Bagoes. 2000. Demografi Umum. Yogyakarta: Pustaka Pelajar. 